\title{
PULSATILE SECRETION OF GONADOTROPIN-RELEASING HORMONE BY RAT HYPOTHALAMIC EXPLANTS OF GNRH NEURONS WITHOUT CELL BODIES
}

Gentiane Purnelle, Arlette Gerard, Vincent Czajkowski, Jean-Pierre Bourguignon

Division of Pediatric and Adolescent Medicine, Department of Pediatrics, University of Liege, CHU Sart Tilman, Liège, Belgium

KEYWORDS: Gonadotropin-releasing hormone - Excitatory amino acids - Rhythms

\section{ABSTRACT}

Gonadotropin-releasing hormone $(\mathrm{GnRH})$ is typically secreted in a pulsatile manner. It is still unclear whether pulsatility depends on a GnRH pulse generator residing in the $\mathrm{GnRH}$ neurons or in other neurons. Since the cell bodies of $\mathrm{GnRH}$ neurons are located rostrally to the optic chiasm and the majority of $\mathrm{GnRH}$ terminals in the median eminence of the rat hypothalamus, we have compared $\mathrm{GnRH}$ secretion from individual preoptic, retrochiasmatic and median eminence explants using a static incubation system. GnRH is released from the three different types of explant in response to depolarization with veratridine or glutamate receptor stimulation using the agonist $\mathrm{N}$-methyl- $D$-aspartate. Only the retrochiasmatic explants, however, show a characteristic pulsatile secretion of $\mathrm{GnRH}$. The mean $( \pm \mathrm{SD})$ interpulse interval is respectively $37+5,25 \pm 4$ and 12 \pm 1 min when the fractions are collected at 7.5-, 5.0- and 2.5-min intervals. The immunocytochemically stained GnRH cell bodies are normally distributed in the preoptic explants ( $n=212-420$ ) while only $3 \mathrm{GnRH}$ cell bodies can be visualized in 7 retrochiasmatic explants. Semiquantitative RT-PCR shows that GnRH mRNA is present in the retrochiasmatic explant in a ratio of about 1:600 relative to the preoptic explant. We conclude that pulsatile GnRH secretion occurs in the virtual absence of $\mathrm{GnRH}$ cell bodies but does not occur from GnRH terminals in the isolated median eminence. These data further indicate that a mechanism of $\mathrm{GnRH}$ pulsatility is located in the retrochiasmatic hypothalamus and involves neurons different from the $\mathrm{GnRH}$ neurons. 


\section{Introduction}

Gonadotropin-releasing hormone $(\mathrm{GnRH})$ is secreted in a pulsatile manner which is critical for pituitary gonadotropin secretion in different species [1-3]. Knobil [4] has proposed the existence of a hypothalamic pulse generator evidenced through the periodic electrophysiological manifestations preceding luteinizing hormone (LH) secretory pulses. Whether GnRH pulsatility is generated in the $\mathrm{GnRH}$ neurons or through a distinct neuronal apparatus remains elusive. In the rat, the mediobasal hypothalamus retains its capacity to secrete $\mathrm{GnRH}$ in a pulsatile manner when deafferented in vivo $[5,6]$ or when studied in vitro $[7,8]$. Since such an isolated hypothalamus does presumably not contain GnRH cell bodies which are located in the preoptic area [9], the existence of a pulse-generating mechanism external to the GnRH neurons is suggested. Recently, however, it has been proposed that $\mathrm{GnRH}$ neurons have the intrinsic capacity to generate secretory pulses since the immortalized GnRH neurons (GT-1 cell line) can release GnRH in an intermittent manner $[10,11]$. Alternatively, some mechanism of $\mathrm{GnRH}$ pulsatility could reside in the terminals independently of neuronal cell bodies since pulsatile GnRH secretion has been shown using the isolated median eminence [12]. The aim of this study was to show whether the cell bodies of GnRH neurons are required or whether $\mathrm{GnRH}$ terminals suffice to elicit pulsatile secretion of $\mathrm{GnRH}$ from hypothalamic explants.

\section{Materials and Methods}

\section{ANIMALS AND EXPLANT DISSECTION}

Adult male Wistar rats were housed under standardized conditions of temperature $\left(25^{\circ} \mathrm{C}\right)$ and light darkness rhythm (12/12 h) with free access to food and water. The animals were studied at 50 days of age.

After decapitation, the preoptic and retrochiasmatic explants of the hypothalamus were dissected through 3 coronal incisions: $2 \mathrm{~mm}$ rostrally to the optic chiasm, at the caudal border of the optic chiasm and at the rostral border of the mamillary bodies. Two lateral incisions along the lateral sulci and a $2 \mathrm{~mm}$ deep frontal section were made to obtain the preoptic and retrochiasmatic explants. The median eminence was dissected following a procedure described by Negro-Vilar et al. [13].

\section{EXPLANT INCUBATION AND GNRH RADIOIMMUNOASSAY}

The explants were studied using a static incubation procedure which was described in detail previously $[7,8]$. In a first experiment, 10 individual retrochiasmatic explants and the corresponding preoptic explants were studied. In a second experiment, 5 retrochiasmatic explants 
and 5 median eminences were studied. They were incubated individually in $0.5 \mathrm{ml}$ Eagle's Minimum Essential Medium (Flow, McLean, Va., USA) supplemented with glycine, magnesium, glucose and bacitracin to achieve concentrations of $10 \mathrm{nM}, 1 \mathrm{mM}, 25 \mathrm{mM}$ and $20 \mu \mathrm{M}$, respectively. The medium was collected and renewed every 7.5 min during $4 \mathrm{~h}$. At the end of the experiment, the release of GnRH was evoked by incubation for 7.5 min using $50 \mu \mathrm{M}$ of veratridine, a $\mathrm{Na}^{+}$channel opener (Sigma) and, $30 \mathrm{~min}$ later, $50 \mathrm{mM}$ of $\mathrm{N}$-methyl-D-aspartate (NMDA, Sigma). In a third experiment, retrochiasmatic explants were incubated and the fractions for $\mathrm{GnRH}$ assay were collected at different intervals $(15,7.5,5$ and $2.5 \mathrm{~min}, 10$ explants studied for each sampling interval). The collected samples were frozen until assayed.

GnRH was measured in the collected fractions using the specific RR-5 antiserum (provided by Dr. A. Root). This RIA procedure has been described previously [7, 8]. The limit of sensitivity was $5 \mathrm{pg} / 7.5-\mathrm{min}$ fractions which was the value assigned to samples with undetectable GnRH level. The release of GnRH evoked by NMDA or veratridine was calculated as the difference between the amounts of GnRH secreted immediately prior to and during incubation with the secretagogue.

\section{IMMUNOCYTOCHEMISTRY}

Seven rats anesthetized using chloral hydrate received intracardiac perfusion of Zamboni's buffered picric acid-paraformaldehyde fixative ( $\mathrm{pH}$ 7.4). The brains were dissected and incubated overnight in the fixative at $4^{\circ} \mathrm{C}$. After overnight washing in PBS $0.02 \mathrm{M}$ containing $30 \%$ sucrose, the brains were embedded in OCT, frozen on dry ice and sectionned at $14 \mu \mathrm{m}$ on a cryostat. After preincubation with PBS $0.02 \mathrm{M}$ containing $10 \%$ normal swine serum and $0.1 \%$ Triton X-100 and washing, the sections were incubated during 4 or 5 days at $4^{\circ} \mathrm{C}$ with the anti-GnRH LR1 antiserum (a generous gift from Dr. R. Benoit, Montreal, Canada), diluted at 1:2,000. This antiserum was previously characterized [14], After washing, the sections were incubated sequentially with biotinylated swine anti-rabbit immunoglobulins (Prosan, Glastrup, Denmark), used overnight at $4^{\circ} \mathrm{C}$ at 1:200 dilution and StreptAB Complex (Prosan) at room temperature. Staining was obtained using 3,3'-diaminobenzidine (with $\beta-D(+)$ glucose and glucose oxydase) and counterstaining using hematoxylin. All the sections were screened for GnRH-immunoreactive neuronal cell bodies, paying attention to avoid double cell counting.

\section{REVERSE TRANSCRIPTASE-POLYMERASE CHAIN REACTION}

After decapitation of 50-day-old male rats, the preoptic and retrochiasmatic explants were dissected and rapidly frozen in RNase-free liquid nitrogen. The samples were weighed and stored at $-70^{\circ} \mathrm{C}$. Total RNAs were extracted according to the RNAzol method [15] and stored at $-70^{\circ} \mathrm{C}$. The extracted RNAs were quantified by UV-spectroscopic measurement and the absence of degradation was assessed by electrophoresis on formaldehyde agarose denaturating gel. Based on the rat GnRH cDNA sequence [16,17], GnRH primers were synthesized using the following oligonucleotide sequences which were proposed by Kim et al. [18]. Upstream primer: $5^{\prime}$ CACTATGGTCACCAGCGGGG 3' (sequence 894-913; exon 1; accession number $M$ 31670) and downstream primer: 5'AGAGCTCCTCGCAGATCCCTAAGA 3' (sequence 3,635-3,658; exon 3; 
accession number M 31670). The predicted size of this PCR product is $375 \mathrm{bp}[16,17]$, As positive and semi-quantitative controls, the upstream and downstream primers of $\beta$-actin were used: 5'GATGGTGGGTATGGGTCAGAAGGA 3' and 5'GCTCATTGCCGATAGTGATGACCT 3' [19], The predicted size of this PCR product is $632 \mathrm{bp}$. All primers were chosen to flank introns so that the amplified $\mathrm{GnRH}$ and $\beta$-actin $\mathrm{CDNAs}$ can be distinguished from an amplification of possible contaminating genomic DNA.

Reverse transcriptase and PCR were performed in a one-step method, using the RNA PCR PerkinElmer kit. Briefly, $10 \mu \mathrm{g}$ of total RNAs were reverse transcribed into CDNAs with an oligodeoxythymidilate-oligo (dT) as primer, in a volume of $20 \mu \mathrm{l}\left(10 \mathrm{~min}\right.$ at $70^{\circ} \mathrm{C}, 60 \mathrm{~min}$ at $42^{\circ} \mathrm{C}$ and $5 \mathrm{~min}$ at $4^{\circ} \mathrm{C}$ ). The reaction mixture contained $25 \mathrm{mM} \mathrm{MgC1} 1_{2}, 1 \mathrm{mM}$ dNTP mix, $1 \mathrm{U} / \mu \mathrm{l}$ RNAse inhibitor, $2.5 \mu \mathrm{l} / \mathrm{ml}$ M-MuLV reverse Transcriptase (Eurogentec, Liege, Belgium) and $2.5 \mu \mathrm{M}$ oligo (dT)16. The cDNAs obtained were amplified in the presence of DNA polymerase (Goldstar, Eurogentec) and the specific primers. PCR was performed in a Perkin-Elmer PCR automated thermocycler with the following cycles: $1.5 \mathrm{~min}$ at $94^{\circ} \mathrm{C}$ (denaturation), $1.5 \mathrm{~min}$ at $60^{\circ} \mathrm{C}$ (primer annealing) and $1.5 \mathrm{~min}$ at $72^{\circ} \mathrm{C}$ (primer extension) followed by a post-PCR incubation during $10 \mathrm{~min}$ at $72^{\circ} \mathrm{C}$. Negative controls (water instead of CDNA) were run in parallel. Ten micrograms preoptic RNAs and $10 \mu \mathrm{g}$ retrochiasmatic RNAs were used for PCR. After 20 cycles, $5 \mu \mathrm{l}$ of the preoptic medium were diluted at 1:75, 1:100, 1:150, 1:200 and 1:300 in the PCR mixture. PCR was allowed to run again to cycle 50 for the different dilutions of the preoptic product and for the retrochiasmatic product. The PCR products were studied through electrophoresis on $1.5 \%$ agarose gel in TAE buffer, stained with ethidium bromide and photographed under UV illumination. An electronic densitometric scanning of PCR product signals was directly processed from agarose gel under UV transilluminator with a black and white high-sensitive CCD camera connected to an IBM personal computer. Densitometric scanning of the $\beta$-actin bands at different PCR cycles (23-27) indicated that the extraction rates were similar in the preoptic and the retrochiasmatic explant. As specificity controls, PCR products from preoptic and retrochiasmatic mRNAS were digested with Eac 1 , Hha 1 and Tag 1. This resulted in the following anticipated fragments: 162 and $213 \mathrm{bp}, 231$ and $144 \mathrm{bp}$, 321 and 54 bp as predicted by analysis of restriction sites (data not shown).

\section{STATISTICAL ANALYSIS}

The occurrence of significant pulses of GnRH secretion was determined using the Pulsar program $[20,21]$ as described previously [22]. The individual interpulse intervals and the mean \pm SD intervals were calculated. The coefficient of variation (CV) of the interpulse interval was also calculated. The significance of difference in mean GnRH release evoked by veratridine or NMDA was calculated using the unpaired Student's t test. 
Fig. 1. Representative profiles of $\mathrm{GnRH}$ secretion by 4 individual explants of the retrochiasmatic hypothalamus (A) and the corresponding preoptic hypothalamus (B). The mean ( \pm I SD) GnRH release evoked by veratridine (50 $\mu \mathrm{M})$ and NMDA (50 mM) is studied using 6 individual retrochiasmatic (C) or preoptic (D) explants. The dashed line indicates the limit of sensitivity of the GnRH assay. $\bullet=$ Significant pulse detected by the Pulsar program.

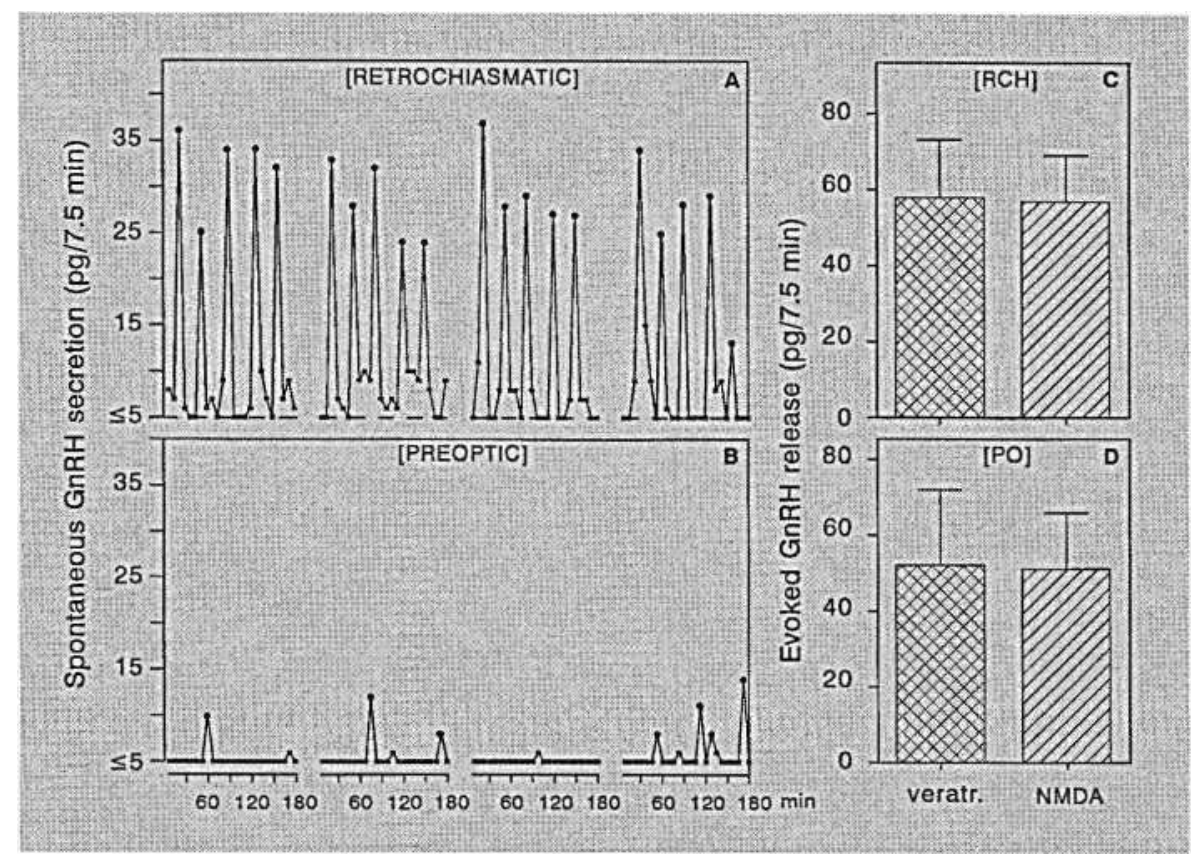

Fig. 2. Representative profiles of $\mathrm{GnRH}$ secretion by 5 individual explants of the retrochiasmatic hypothalamus including the median eminence (A) or the median eminence only (B). The mean ( \pm 1 SD) GnRH release evoked by veratridine $(50 \mu \mathrm{M})$ and NMDA $(50 \mathrm{mM})$ is studied using the retrochiasmatic (C) or median eminence (D) explants. The dashed line indicates the limit of sensitivity of the GnRH assay. $\bullet=$ Significant pulse detected by the Pulsar program.

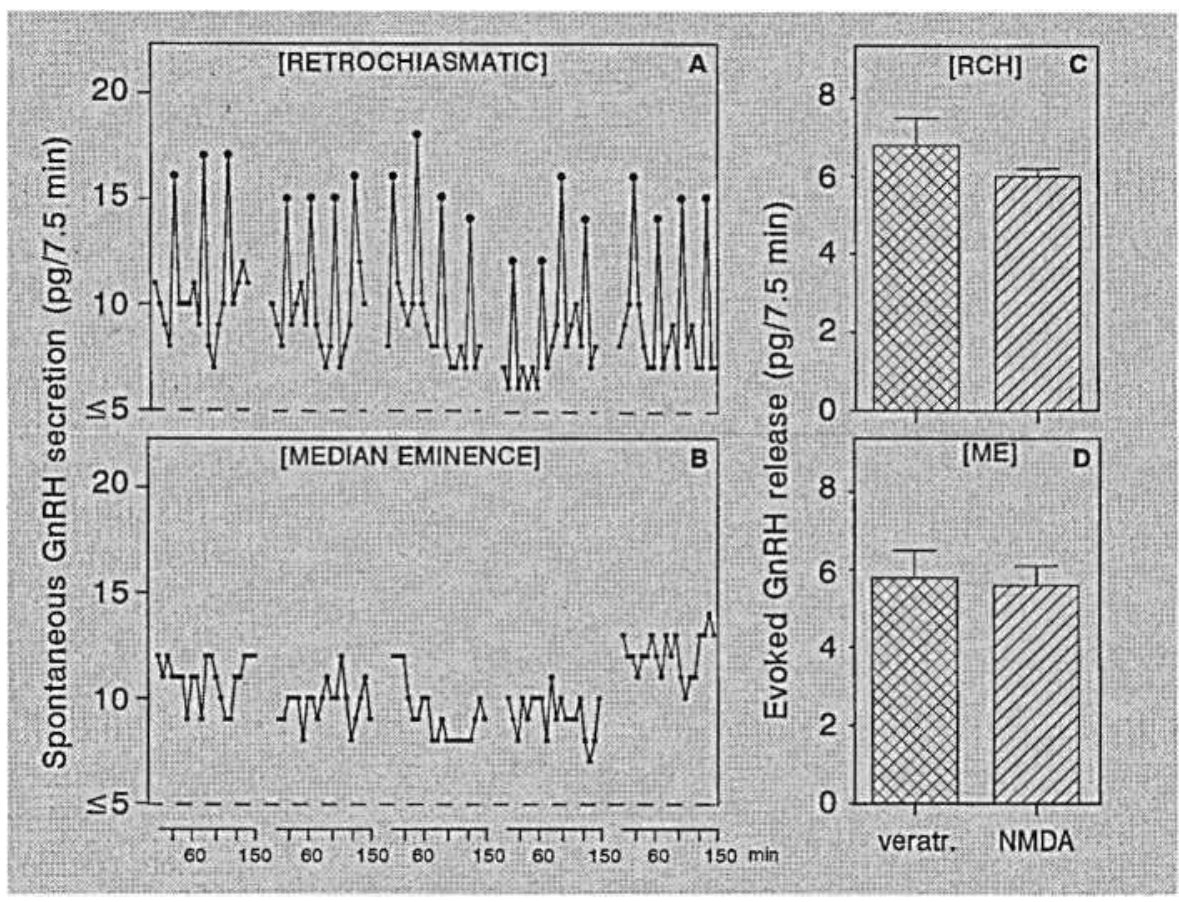


Fig. 3. Distribution of GnRH interpulse intervals observed during static incubation of individual retrochiasmatic explants from 50-day-old rats and collection of fractions at intervals of 15 (a), 7.5 (b), 5 (c) or 2.5 min (d). The CV of the GnRH interpulse interval is given in each condition.

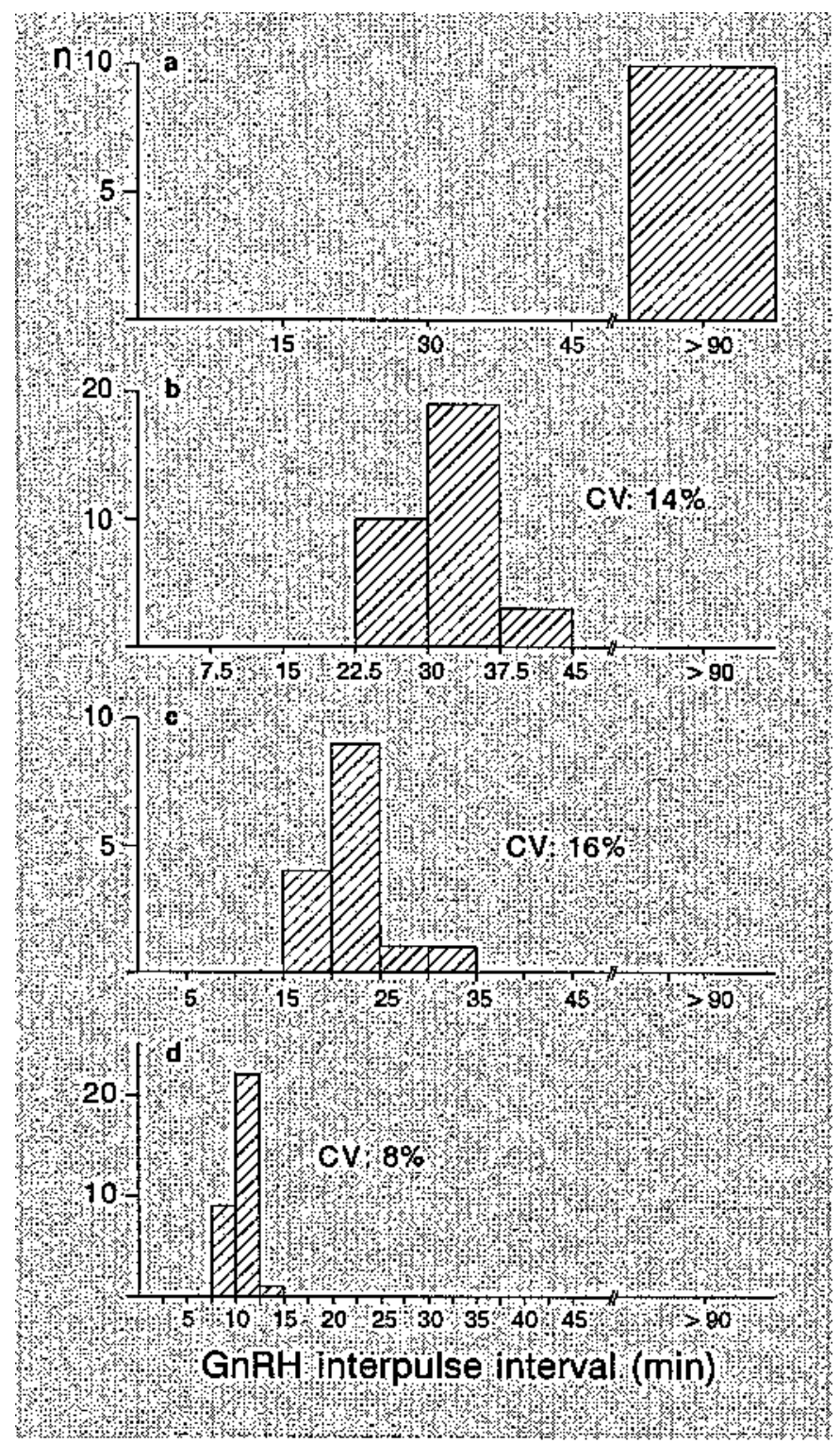

\section{Results}

The retrochiasmatic explants exhibit a spontaneous pulsatile pattern of GnRH secretion (fig. 1A, 2A). The mean interpulse interval is $34.7 \pm 3.9 \mathrm{~min}$ (fig. $1 \mathrm{~A}$ ) or $37.9 \pm 4.5 \mathrm{~min}$ (fig. $2 \mathrm{~A}$ ). Using the preoptic explants, few irregular pulses of low amplitude are seen (fig. 1B). Using the median eminences, no GnRH secretory pulses are observed (fig. 2B). The release of GnRH evoked by veratridine or NMDA is similar using the retrochiasmatic (fig. 1C) and preoptic explants (fig. 1D). Likewise, a similar GnRH release is evoked by veratridine or NMDA using the retrochiasmatic (fig. 2C) and median eminence explants (fig. 2D). Using retrochiasmatic explants, the GnRH interpulse 
interval is a function of the sampling interval (fig. 3). Using 15- min fractions, no more than one single pulse was secreted by each explant during a study period of $180 \mathrm{~min}$. Therefore, the interpulse interval could not be calculated (>90 min). Using 7.5-, 5- and 2.5- min fractions, the interpulse intervals show a respective reduction: $37 \pm 5,25 \pm 4$ and $12 \pm 1 \mathrm{~min}$. In those conditions, the intervals between $\mathrm{GnRH}$ pulses are distributed in a relatively narrow range with a similar pattern peaking at 37.5, 25 and $12.5 \mathrm{~min}$ (fig. 3).

Immunocytochemical study of the preoptic explant shows the normal distribution of GnRH cell bodies in that region (fig. 4). The total number of cell bodies found in 7 preoptic explants varies between 212 and 420. Among the 7 retrochiasmatic explants studied thoroughly, only one GnRH cell body can be observed in three of them. These cell bodies are located at the border of the optic chiasm, in the vicinity of the section separating the 2 explants. In the median eminence area, the convergent network of $\mathrm{GnRH}$ fibers is observed.

Using RNAs extracted from preoptic explants, the RT-PCR reproducibly generates a (Lactin band of $632 \mathrm{bp}$ and a GnRH band of $375 \mathrm{bp}$. Using RNAs from retrochiasmatic explants, the RT-PCR generates a (Lactin band and a slight GnRH band. Gel electrophoresis of the RT-PCR products (fig. 5) shows that the intensity of the GnRH band from retrochiasmatic extracts is similar to that obtained from the 1:200 diluted preoptic extract. Taking into account the difference in tissue weight and RNAs obtained from preoptic and retrochiasmatic explants, it can be estimated that $\mathrm{GnRH}$ mRNA is distributed in retrochiasmatic and preoptic explants in a ratio of about 1:600.

Fig. 4. Rostrocaudal distribution of cell bodies of GnRH neurons in the hypothalamus of a 50-day-old male rat. Each bar represents the data from 3 adjacent coronal sections of $14 \mu \mathrm{m}$. The level of dissection between the preoptic and retrochiasmatic explants is indicated.

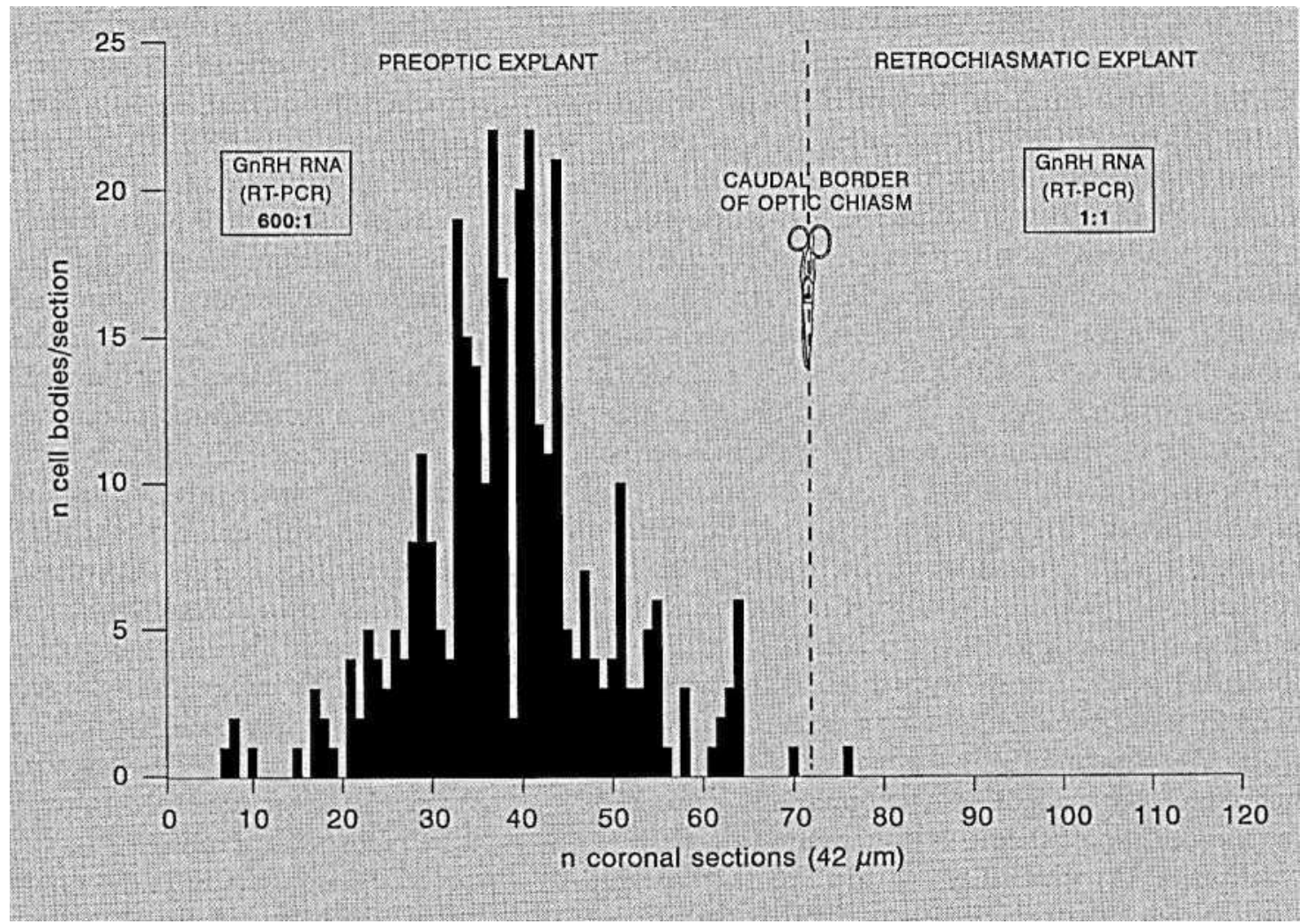


Fig. 5. Electrophoresis of $R T-P C R$ products $(10 \mu l)$ from $R N A$ s extracted from the retrochiasmatic $(R C H)$ and preoptic $(P O)$ parts of the rat hypothalamus. $P M=1-k b$ DNA ladder. For each band $(A-G)$, the RNA origin, the number of $P C R$ cycles and the studied concentration are shown. Densitometric analysis indicates that the amount of retrochiasmatic $P C R$ products $(B)$ is comparable to the 1:200 dilution of preoptic $P C R$ products $(F)$.

\begin{tabular}{|c|c|c|c|c|c|c|c|}
\hline & PM & A & B & c & D & $\mathrm{E}$ & $\mathrm{F}$ \\
\hline origin & & PO & $\mathrm{RCH}$ & PO & PO & PO & PO \\
\hline$n$ cycles & & 45 & 50 & 50 & 50 & 50 & 50 \\
\hline oncentr. & & $1 / 1$ & $1 / 1$ & $1 / 75$ & $1 / 100$ & $1 / 150$ & $1 / 200$ \\
\hline
\end{tabular}

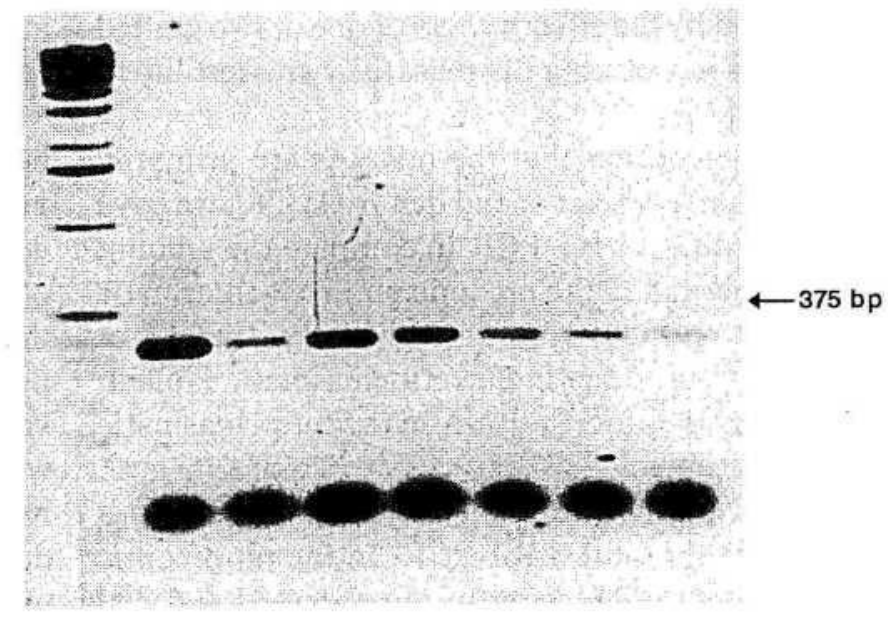

\section{Discussion}

In this paper, we show that retrochiasmatic explants of the rat hypothalamus secrete GnRH in a pulsatile manner in the absence of $\mathrm{GnRH}$ cell bodies. In contrast, only few irregular pulses are observed using explants of the preoptic hypothalamus where $\mathrm{GnRH}$ cell bodies are located and no pulses are seen using explants of the median eminence. The absence of GnRH cell bodies in the retrochiasmatic area of the rat hypothalamus is consistent with previous observations [9, 23-25]. We found a single GnRH cell body in some of the studied retrochiasmatic explants. This raises the question as to whether a single retrochiasmatic GnRH neuron may be sufficient to act as pulse generator. Pulsatile LH secretion can be restored in the hpg mouse by third-ventricular graft of fetal preoptic tissue containing as few as one single GnRH neuron [26]. In such experiments, however, it is possible that GnRH synthesized by a single neuron is stored in the median eminence in a sufficient amount for pulsatile secretion driven by a pulse generator in the arcuate nucleusmedian eminence area. This hypothesis is supported by experiments in rats with hypothalamic deafferentation which show restoration of LH pulsatility by third ventricular graft of mediobasal hypothalamic tissue containing no GnRH neurons [27], The observation of GnRH pulsatility in the absence of $\mathrm{GnRH}$ cell bodies also raises the question as to whether synchronization or integrated activation of different $\mathrm{GnRH}$ neurons is a critical component of pulsatile GnRH secretion. 
Synchronization may in fact occur at the axon-terminal level of GnRH neurons if the pulse generator involves the input of external neurons in the retrochiasmatic hypothalamus. Evidence against communication between $\mathrm{GnRH}$ cell bodies as a prerequisite to pulsatility is provided by the effectiveness of one or two grafted GnRH neurons in restoring LH pulsatility and fertility in the hpg mouse [26].

Based on the concept that the mRNAs are primarily located in neuronal perikarya and dendrites [28], we have used semi-quantitative RT-PCR to compare the amount of GnRH transcripts in the preoptic and retrochiasmatic explants. These results are consistent with the presence of very few GnRH cell bodies in the retrochiasmatic explant. The low amount of GnRH mRNA in the retrochiasmatic explant is in agreement with the observations of Kim et al. [18] who have used the mediobasal hypothalamus as a negative control for GnRH RT-PCR. In the rat preoptic area, hundreds of GnRH neurons are observed and distributed as described previously [9,24,25,27,29]. In this respect, the rat hypothalamus provides an original model to separate the GnRH cell bodies from their terminals since in other species such as man, the monkey and guinea pig, the GnRH neurons migrate more caudally in the retrochiasmatic area [30-32], The similar amplitudes of GnRH release evoked by veratridine and NMDA using the preoptic and retrochiasmatic explants attest that GnRH axon-terminals and NMDA receptors are present in these two regions and are still functional at the end of the in vitro experiment. This observation is consistent with the existence of $\mathrm{GnRH}$ axon projection to the median eminence in the retrochiasmatic explant as well as to the organum vasculosum of the lamina terminalis in the preoptic explant [33-35]. Thus, the absence of GnRH pulsatility using the preoptic explant cannot be explained by the absence of functional GnRH terminals since neurosecretion of GnRH can be evoked from this fragment.

The localization of a pulse generator mechanism at the GnRH terminal level was suggested by the observation of episodic GnRH release from the isolated rat median eminence as reported by Rasmussen et al. [12], However, using median eminence explants in the same conditions as the retrochiasmatic explants, we did not obtain any evidence of pulsatile GnRH secretion. This cannot be explained by an altered viability of the preparation since GnRH release could be evoked through depolarization or NMDA receptor stimulation in a manner which was similar to that seen using retrochiasmatic explants. Thus, while the median eminence appears to contain the components required for the autofeedback to be operational, pulsatility is not observed in our conditions. We cannot exclude that dissection of the median eminence has resulted in the loss of some anatomical structures involved in a pulse generator. Taken together, our data suggest the existence of a retrochiasmatic GnRH pulse generator mechanism which is external to the GnRH cell bodies and the $\mathrm{GnRH}$ terminals.

The question was raised whether methodological aspects such as periodic agitation when the incubation medium was renewed, could account for pulsatility. Indeed, the GnRH interpulse interval changed as a function of the sampling interval. Using a perifusion system where the samples were drawn at constant interval and varying flow rate, flow rate dependency of GnRH interpulse interval was observed as well [36]. Thus, mechanical factors were unlikely to be involved and the effect of sampling interval should not be biased by missing pulses not detected when that 
interval was too long. While the frequency of pulsatile $\mathrm{GnRH}$ secretion seen in different experiments was reproducible, important variations in $\mathrm{GnRH}$ pulse amplitude were seen from one experiment to the other. It was therefore important to compare two types of explants in the same experiment as we did. A useful parameter in the evaluation of pulsatility is regularity of the process. This can be estimated through the distribution of $\mathrm{GnRH}$ interpulse intervals. While we found that the interpulse interval was distributed within 3-4 fractions of $7.5 \mathrm{~min}$ (coefficient of variation, CV: 8-16\%), it was more variable in the study by Rasmussen [12] using the median eminence. From his data, we calculated a CV of 53-56\%. That difference in CV is unlikely to be explained by the incubation system since Rasmussen et al. [37] observed a more regular periodicity using perifused human mediobasal hypothalami in vitro (CV: $35 \%)$. More recently, other authors also reported pulsatile GnRH secretion showing less variable intervals using the mediobasal hypothalamus than using preoptic explants [38], We tend to conclude that different mechanisms of episodic GnRH secretion may coexist because pulsatility is less regular using the median eminence than using the retrochiasmatic or mediobasal hypothalamus.

The mechanism of pulsatile GnRH secretion from the retrochiasmatic explants of the rat hypothalamus is not fully elucidated. The present data are consistent with an inhibitory autofeedback regulation of $\mathrm{GnRH}$ pulsatility. An autoregulatory mechanism of pulsatility is supported by the demonstration of an inhibitory autofeedback of GnRH which can affect the frequency of pulsatile secretion [39], possibly through NMDA receptor antagonism by 1-5 GnRH, a physiological degradation product of the secreted decapeptide [40].

The developmental increase in GnRH pulse frequency which precedes the onset of puberty, is observable using our in vitro paradigm. This indicates that not only a pulse generator but also the neuronal network involved in maturational changes are located in the retrochiasmatic area [7, 22, 39]. In agreement with our data, in vivo electrophysiological experiments suggest that a GnRH pulse generator is located in the rat arcuate nucleus instead of the median eminence or the preoptic area [41] and deafferentation studies show that integrity of the arcuate nucleus is required to maintain a pulsatile LH secretion $[5,6]$. Such a concept is also consistent with our recent demonstration that antisense oligodeoxynucleotides for some subunits of NMDA or GABA receptors can affect pulsatile $\mathrm{GnRH}$ secretion in the absence of the preoptic area [42, 43]. Finally, it is of interest that mathematical modelization of the GnRH pulse generator has come to the conclusion that a minimal external neuronal unit with a facilitatory neuron and an inhibitory interneuron should be involved [44]. Virtually, every neuron has the capacity to function as a pacemaker. The challenge remains to determine where in the hypothalamus and which type of neurons will superimpose their periodic activity on that of the other neurons to result in the characteristic pulsatility of LH secretion.

\section{Acknowledgments}

We are grateful to Dr. A. Root (St. Petersburg, Fla., USA) who provided us generously with the RR-5 anti-GnRH antiserum and to Dr. R. Benoit (Montreal, Que., Canada) for the gift of LR1 antiserum. We 
thank Prof. J. Martial for assistance in RT-PCR studies and Dr. M. Lemaitre (Eurogentec) for the supply of the oligoprobes. We also thank Ms. J. Laurent for secretarial assistance. Supported by grants from the "Fonds de la Recherche Scientifique Medicale de Belgique" No. 3.4583.93), the Faculty of Medicine of the University of Liege and the Belgian Study Group for Pediatric Endocrinology. 


\section{References}

1 Wildt L, Hausler A, Marshall G, Hutchinson GS, Plant TM, Belchetz PE, Knobil E: Frequency and amplitude of gonadotropin-releasing hormone stimulation and gonadotropin secretion in the rhesus monkey. Endocrinology 1981; 109: 376-385.

2 Clarke JJ, Cummins JT: The temporal relationship between gonadotropin releasing hormone $(\mathrm{GnRH})$ and luteinizing hormone secretion in ovariectomized ewes. Endocrinology 1982; 111: 1737-1739.

3 Levine JE, Duffy MT: Simultaneous measurement of luteinizing hormone-releasing hormone, LH, and follicle-stimulating hormone release in intact and short-term castrate rats. Endocrinology 1988; 5: 22112221.

4 Knobil E: The neuroendocrine control of the menstrual cycle. Recent Prog Horm Res 1980; 36: 53-88.

5 Blake CA, Sawyer CH: Effects of hypothalamic deafferentation on the pulsatile rhythm in plasma concentration of LH in ovariectomized rats. Endocrinology 1974; 94: 730-736.

6 Soper BD, Weick RF: Hypothalamic and extra- hypothalamic mediation of pulsatile discharges of luteinizing hormone in the ovariectomized rat. Endocrinology 1980; 106: 348-355.

7 Bourguignon JP, Franchimont P: Puberty-related increase in episodic LHRH release from rat hypothalamus in vitro. Endocrinology 1984; 114: 1941-1943.

8 Bourguignon JP, Girard A, Mathieu J, Simons J, Franchimont P: Pulsatile release of gonadotropin releasing hormone from hypothalamic explants is restrained by blockade of $\mathrm{N}$-methyl-D,L-aspartate receptors. Endocrinology 1989; 125: 1090-1096.

9 Silverman AJ: The gonadotropin-releasing hormone $(\mathrm{GnRH})$ neuronal systems: Immunocytochemistry; in Knobil E, Neill J (eds): The Physiology of Reproduction. New York, Raven Press 1988, pp 1283-1304.

10 Martinez de la Escalera G, Choi ALH, Weiner RI: Generation and synchronization of gonadotropinreleasing hormone $(\mathrm{GnRH})$ pulses: Intrinsic properties of the GT1-1 GnRH neuronal cell line. Proc Natl Acad Sci USA 1992; 89: 1852-1855.

11 Wetsel WC, Valeria MM, Mcrchenthaler I, Liposits Z, Lopez FJ, Weiner RI, Mellon PL, Negro-Vilar A: Intrinsic pulsatile secretory activity of immortalized luteinizing hormone-releasing hormone-secreting neurons. Proc Natl Acad Sci USA 1992; 89: 4149-4153.

12 Rasmussen DD: Episodic gonadotrophin-releasing hormone release from the rat isolated median eminence in vitro. Neuroendocrinology 1993; 58: 511-518.

13 Negro-Vilar A, Ojeda SR, McCann SM: Catecholaminergic modulation of luteinizing hormonereleasing hormone release by median eminence terminals in vitro. Endocrinology 1979; 104: 1749-1757.

14 Silverman AJ, Witkin JW, Millar RP: Light and electron microscopic immunocytochemical analysis of antibodies directed against GnRH and its precursor in hypothalamic neurons. J Cytochem Histochem 1990; 38: 803-813.

15 Chomczynski P, Sacchi N: Single-step method of RNA isolation by acid guanidinium thiocyanatephenol-chloroform extraction. Anal Biochem 1987; 162: 156-159. 
16 Adelman JP, Mason AJ, Hayflick JS, Seeburg PH: Isolation of the gene and hypothalamic CDNA for the common precursor of gonadotrophin-releasing hormone and prolactin release inhibiting factor in human and rat. Proc Natl Acad Sci USA 1986; 83: 179-183.

17 Bond CT, Hayflick JS, Seeburg PH, Adelman JP: The rat gonadotrophin-releasing hormone: SH locus: Structure and hypothalamic expression. Mol Endocrinol 1989; 3: 1257-1262.

18 Kim K, Jarry H, Knoke I, Seong JY, Leonhardt S, Wuttke W: Competitive PCR for quantitation of gonadotropin-releasing hormone mRNA level in a single micropunch of the rat preoptic area. Mol Cell Endocrinol 1993; 97: 153-158.

19 Yamada M, Satoh T, Monden T, Murakami M, Iriuchijima T, Wilber JF, Mori M: Influences of hypothyroidism on TRH concentrations and preproTRH mRNA levels in rat hypothalamus: A simple and reliable method to detect preproTRH mRNA level. Neuroendocrinology 1992; 55: 317-320.

20 Merriam GR, Wachter KW: Algorithms for the study of episodic hormone secretion. Am J Physiol 1982; 243: E310-E318.

21 Gitzen JF, Ramirez VD: PC Pulsar-Pulsar pulse analysis for the IBM-PC. Psychoneuroendocrinology 1987; 12: 3-6.

22 Bourguignon JP, Gerard A, Mathieu J, Marthieu A, Franchimont P: Maturation of the hypothalamic control of pulsatile gonadotropin-releasing hormone secretion at onset of puberty. I. Increased activation of $\mathrm{N}$-methyl-D-aspartate receptors. Endocrinology 1990; 127: 873-881.

23 Ellinwood WE, Ronnekleiv OK, Kelly MJ, Resko JA: A new antiserum with conformational specificity for LHRH: Usefulness for radioimmunoassay and immunocytochemistry. Peptides 1985; 6: 45-52.

24 Ronnekleiv OK, Naylor BR, Bond CT, Adel-man JP: Combined immunohistochemistry for gonadotropin-releasing hormone ( $\mathrm{GnRH}$ ) and Pro-GnRH, and in situ hybridization for $\mathrm{GnRH}$ messenger ribonucleic acid in rat brain. Mol Endocrinol 1989; 3: 363-371.

25 Kawano H, Daikoku S: Immunohistochemical demonstration of LHRH neurons and their pathways in the rat hypothalamus. Neuroendocrinology 1981; 32: 179-186.

26 Kokoris GJ, Lam NY, Ferin M, Silverman AJ, Gidson MJ: Transplanted gonadotropin-releasing hormone neurons promote pulsatile luteinizing hormone secretion in congenitally hypo-gonadal (hpg) male mice. Neuroendocrinology 1988; 48: 45-52.

27 Ohkura S, Tsukamura H, Maeda KI: Effects of transplants of fetal mediobasal hypothalamus on luteinizing hormone pulses impaired by hypothalamic deafferentation in adult ovariectomized rats. Neuroendocrinology 1992; 55: 422-426.

28 Davis L, Banker GA, Steward O: Selective dendritic transport of RNA in hippocampal neurons in culture. Nature 1987; 330: 477-479.

29 Witkin JW, Paden CM, Silverman AJ: The luteinizing hormone-releasing hormone (LHRH) systems in the rat brain. Neuroendocrinology 1982; 35: 429-438.

30 Silverman AJ: Distribution of luteinizing hormone releasing hormone (LHRH) in the guinea pig brain. Endocrinology 1976; 99: 30-41.

31 King JC, Anthony ELP: LHRH neurons and their projections in humans and other mammals: Species comparisons. Peptides 1984; 5: 195-207. 
32 Schwanzel-Fukuda M, Morrell JI, Pfaff DW: Ontogenesis of neurons producing luteinizing hormonereleasing hormone in the nervus terminalis of the rat. J Comp Neurol 1985; 238: 348-364.

33 Barry J: Immunocytochemistry of luteinizing hormone releasing hormone-producing neurons of vertebrates. Int Rev Cytol 1979; 60: 179-219.

34 Shivers BD, Harlan RE, Morrell JI, Pfaff DW: Immunocytochemical localization of LHRH in male and female rat brains. Neuroendocrinology 1983; 36: 1-12.

35 Rothfield JM, Gross DS: GnRH within the organum vasculosum of the lamina terminalis in ovariectomized, estrogen/progesterone treated rat: Quantitative immunocytochemical study using image analysis. Brain Res 1985; 338: 309-315.

36 Bourguignon JP, Gerard A, Alvarez Gonzalez ML, Pumelle G, Franchimont P: The role of excitatory amino acids in triggering the onset of puberty; in Plant T, Lee PA (eds): The Neurobiology of Puberty. Bristol, J Endocrinol, 1995, pp 129-138.

37 Rasmussen DD, Gambacciani M, Swartz W, Tueros VS, Yen SSC: Pulsatile gonadotropin-releasing hormone release from the human mediobasal hypothalamus in vitro: Opiate-receptor-mediated suppression. Neuroendocrinology 1989; 49: 150-156.

38 Messager S, Caillol M, Rossano B, Martinet L: Effect of melatonin on the release of gonadotropinreleasing hormone and cyclic AMP from the rat hypothalamus: An in vitro study. J Neuroendocrinol 1996; 8: 801-807.

39 Bourguignon JP, Gerard A, Franchimont P: Maturation of the hypothalamic control of pulsatile gonadotropin-releasing hormone secretion at onset of puberty. II. Reduced potency of an inhibitory autofeedback. Endocrinology 1990; 127: 2884-2890.

40 Bourguignon JP, Alvarez Gonzalez ML, Ge $r$ rard A, Franchimont P: Gonadotropin releasing hormone inhibitory autofeedback by subproducts antagonist at N-methyl- $D$-aspartate receptors: A model of autocrine regulation of peptide secretion. Endocrinology 1994; 134: 1589-1592.

41 Kawakami M, Uemura T, Hayashi R: Electrophysiology correlates of pulsatile gonadotropin release in rats. Neuroendocrinology 1982; 35: 63-67.

42 Bourguignon JP, Gerard A, Pumelle G, Czajkowski V, Yamanaka C, Lemaitre M, Rigo JM, Moonen G, Franchimont P: Duality of glutamatergic and gabaergic control of pulsatile $\mathrm{GnRH}$ secretion by rat hypothalamic explants. I. Effects of antisense oligodeoxynucleotides and role of explant size. J Neuroendocrinol 1997; 9: 183-191.

43 Bourguignon JP, Gerard A, Pumelle G, Czajkowski V, Yamanaka C, Lemaitre M, Rigo JM, Moonen G, Franchimont P: Duality of glutamatergic and gabaergic control of pulsatile GnRH secretion by rat hypothalamic explants. II. Developmental changes at initiation of sexual maturation. J Neuroendocrinol 1997; 9: 193-199.

44 Brown D, Herbison AE, Robinson JE, Marrs W, Leng G: Modelling the luteinizing hormone-releasing hormone pulse generator. Neuroscience 1994; 63: 869-879. 